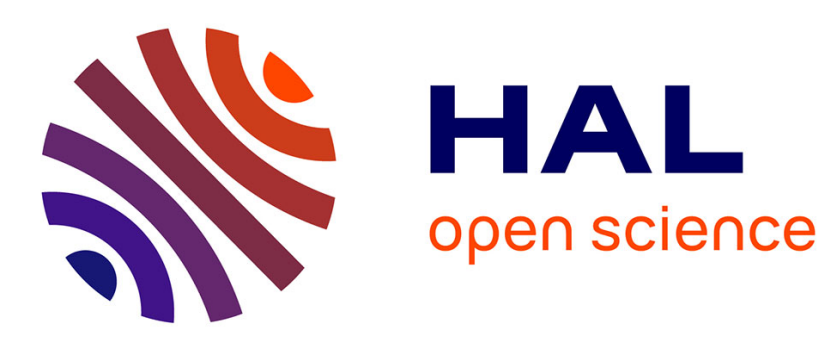

\title{
Digital ulcers as the first manifestation of carpal tunnel syndrome
}

\author{
Katja Perdan-Pirkmajer, Sonja Praprotnik, Matija Tomšič
}

\section{To cite this version:}

Katja Perdan-Pirkmajer, Sonja Praprotnik, Matija Tomšič. Digital ulcers as the first manifestation of carpal tunnel syndrome. Rheumatology International, 2009, pp.685-686. 10.1007/s00296-009-1229-4 . hal-00594495

\section{HAL Id: hal-00594495 \\ https://hal.science/hal-00594495}

Submitted on 20 May 2011

HAL is a multi-disciplinary open access archive for the deposit and dissemination of scientific research documents, whether they are published or not. The documents may come from teaching and research institutions in France or abroad, or from public or private research centers.
L'archive ouverte pluridisciplinaire HAL, est destinée au dépôt et à la diffusion de documents scientifiques de niveau recherche, publiés ou non, émanant des établissements d'enseignement et de recherche français ou étrangers, des laboratoires publics ou privés. 


\title{
Title page
}

Manuscript title: Digital ulcers as the first manifestation of carpal tunnel syndrome

Authors: Katja Perdan-Pirkmajer, Sonja Praprotnik, Matija Tomšič

Corres ponding author: Katja Perdan-Pirkmajer, MD

University Medical Centre,

Department of Rheumatology

Vodnikova 62, 1000 Ljubljana, SLOVENIA

Phone: +386 31314 589, Fax: +3865225598

E-mail: kperdan@yahoo.co.UK

\author{
Co-authors Assist. Prof. Sonja Praprotnik, MD \\ University Medical Centre, \\ Department of Rheu matology \\ Vodnikova 62, 1000 Ljubljana, SLOVENIA \\ Prof. Matija To mšič, MD \\ University Medical Centre, \\ Department of Rheu matology \\ Vodnikova 62, 1000 Ljubljana, SLOVENIA
}

\begin{abstract}
While carpal tunnel syndrome is the most common entrapment neuropathy presented at rheumatologic consultation, its ulcerative variant is rarely described. We report of a case of severe bilateral medial nerve palsy, presented to us for diagnosis of chronic digital u lcers which had been suspected to be rheumatologic in orig in. Careful examination revealed an unusual case of carpal tunnel syndrome in an advanced stage, which presented itself with skin changes only, lacking all the typical neurologic symptoms or rheu matologic backg round. Our case stresses the importance for rheumatologis ts to be aware of the ulcerative form of CTS as one of the etiologic differential diagnostic options of digital u lcers.
\end{abstract}

Key wor ds: carpal tunnel syndrome, dig ital u lcers, acroosteolysis 


\title{
Digital ulcers as the first manifestation of an advanced stage of carpal tunnel syndrome
}

\author{
K. Perdan-Pirkmajer, S. Praprotnik, M. Tomšič
}

Introduction

Carpal tunnel syndrome (CTS) is the most common entrap ment neuropathy presented at rheumatologic consultation [1]. While most CTS are considered to be idiopathic or related to repetitive flexor wrist movements, the presentation of an evolving rheumatologic disease as a CTS is also very well known $[1,2]$. The ulce rative and mutilating clinical variant of CTS was described for the first time by Bouvier and coworkers [3]. It occurs in patients with severe damage of motor, sensory and above all autonomic nerve fibers and usually presents in the advanced stages of disease $[4,5]$. It is characterised by appearance of ulcerative skin laesions, skin atrophy and acroosteolysis in the sensory zones of the median nerve $[5,6]$ as well as nail changes such as onychodystrophy [7].

\section{Case report}

A 85-year old wo man was referred to our Rheu matology department for diagnosis of chronic skin ulcers and blisters which had been reappearing spontaneously for the last 6 years on index and middle fingers bilaterally. She also noticed vesicular laesions beneath the nails, but apart from that, she had no other complaints. She has been treated for hypertension and osteoporosis with ACE inhibitors and biphosphonates for years. Her history of smoking and drinking was negative. She has worked on a farm most of her life.

Index and middle fingers were affected by ulcerations, which were not painful upon palpation (Fig.1). The same fingers were also affected by almost complete loss of the sense of touch. Nails on both index fingers were markedly dystrophic. There was a prominent bilateral thenar atrophy without any appreciable loss of strength in hand grip. Radial pulses were symmetrically palpable. Rheu matologic status was completely normal apart from signs of osteoarthrosis in hands and feet. Laboratory tests revealed slightly elevated erythrocyte sedimentation rate, $24 \mathrm{~mm} / \mathrm{h}(<15)$ and normocytic anaemia, haemoglobin $93 \mathrm{~g} / \mathrm{L}$ (120-160), blood sugar level was normal, Hep-2, ENA, ANCA, cryoglobulines, aPL antibodies were all negative. Hands X-ray showed typical signs of osteoarthrosis of small joints in both hands and bilateral acroosteolysis of distal phalanx of middle fingers. Median nerves were ultrasonically thinned and electrophysiologic findings were consistent with severe bilateral 
median nerve sensori-motor neuropathy. Capillaroscopy revealed no abnormalities. During her stay at our department, most of her ulcers began to heal without any additional therapy (Fig.1).

Discussion

Our patient had typical neurologic deficits, sensori-motor neuropathy with thenar atrophy, skin laesions and onychodytrophy, X-ray evidence of acro-osteolysis and lack of any clinical or laboratory data suggesting inflammatory rheu matologic disease. This was all consistent with severe CTS. Her occupational history also suggested the possibility of an entrap ment neuropathy due to repetitive wrist movements, while normal blood sugar level and radial pulses spoke against diabetes or ischemia contributing to the clinical picture.

Although skin involvement may present in up to $20 \%$ of CTS, there have been but a few reports on it, mostly in dermatologic and surgical literature $[4,7]$. Nevertheless, this is, to our knowledge, the first reported case of a patient with ulcerative variant of CTS, who presented with digital ulcers in an advanced stage of disease, while neurologic signs, which must have developed much earlier, went completely unnoticed by the patient. All the typical symptoms like unrelenting pins and needles, dropping objects and nocturnal pain were absent. Apart from that, ulcerative variant of CTS occurs more often in men and is bilateral in only $25 \%$ of cases $[8]$.

Our case stresses the importance for rheumatologists to be aware of the ulcerative form of CTS as one of the etiologic differential diagnostic options of digital u lcers.

Disclosures: The authors declare no conflict of intersts.

References

1. Gonzalez-Alvaro I, Carvajal I, Estevet M, Lopez-Bote JP, Garcia-Vadillo A (1995) Carpal tunnel syndrome as initial manifestation of inflamatory connective tissues disease. Ann Rheum Dis 54: 782

2. Patil VS, Chopra A (2007) Watch out for 'pins and needles' in hands-it may be a case of gout. Clin Rheu matol $26: 2185-2187$ 
3. Bouvier M, Lejeune E, Rouillat M, Marionnet J (1979) Les formes ulcero-multilantes du syndrome du canal carpien. Rev Rhum Mal Osteoartic 46:169-176

4. Natale M, Spennato P, Bocchetti A, Fratta M, Savarese L, Rotondo M (2005) Ulcerative and mutilating variant of carpal tunnel syndrome. Acta Neurochir 147:905-908

5. Aratari E, Regesta G, Rebora A (1984) Carpal tunnel syndrome appearing with prominent skin symptoms. Arch Dermatol 120:517-519

6. Cox NH, Large DM, Paterson WD (1992) Blisters, ulceration and autonomic neuropathy in carpal tunnel syndrome. Br J Dermatol 126:611-613

7. Fritz TM, Burg G, Böni R (2000) Carpal tunnel syndrome with ulcerous skin lesions. Dermatology 201:165167

8. Romani J, Puig L, de Miguel G, de Morages JM (1997) Carpal tunnel syndrome presenting as sclerodactylia, nail dystrophy and acro-osteolys is in a 60-year old wo man. Dermatology 95:159-161

Figure caption:

Fig1 Digital ulcers on index and middle fingers before (upper insert) and after (lower insert) hospitalisation. 

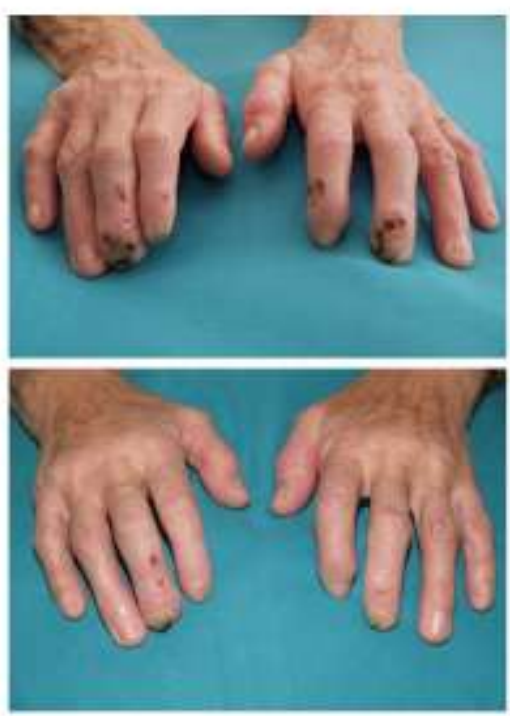